\title{
Body Temperature and Reproductive Performance of Beef Heifers Supplemented With Rumen-Protected Methionine
}

\author{
José Henrique Dominguez \\ Núcleo de Pesquisa, Ensino e Extensão em Pecuária (NUPEEC), Universidade Federal \\ de Pelotas, Pelotas, Rio Grande do Sul, Brazil
}

Matheus Gomes Lopes

Núcleo de Pesquisa, Ensino e Extensão em Pecuária (NUPEEC), Universidade Federal de Pelotas, Pelotas, Rio Grande do Sul, Brazil

Fabrício Amadori Machado

Laboratório de Biotecnologia e Reprodução Animal (BIOREP), Universidade Federal de Santa Maria, Santa Maria, Rio Grande do Sul, Brazil

Ederson dos Santos

Núcleo de Pesquisa, Ensino e Extensão em Pecuária (NUPEEC), Universidade Federal de Pelotas, Pelotas, Rio Grande do Sul, Brazil

Fernanda Lopes

Adisseo Brasil, São Paulo, Brazil

Josiane de Oliveira Feijó

Núcleo de Pesquisa, Ensino e Extensão em Pecuária, Universidade Federal de Pelotas, Pelotas, Rio Grande do Sul, Brazil

Cássio Cassal Brauner

Núcleo de Pesquisa, Ensino e Extensão em Pecuária, Universidade Federal de Pelotas, Pelotas, Rio Grande do Sul, Brazil 
Viviane Rohrig Rabassa

Núcleo de Pesquisa, Ensino e Extensão em Pecuária (NUPEEC), Universidade Federal de Pelotas, Pelotas, Rio Grande do Sul, Brazil

\title{
Marcio Nunes Corrêa
}

Núcleo de Pesquisa, Ensino e Extensão em Pecuária (NUPEEC), Universidade Federal de Pelotas, Pelotas, Rio Grande do Sul, Brazil

\section{Francisco Augusto Burkert Del Pino}

Núcleo de Pesquisa, Ensino e Extensão em Pecuária (NUPEEC), Universidade Federal de Pelotas, Pelotas, Rio Grande do Sul, Brazil

\section{Eduardo Schmitt (Corresponding Author)}

Núcleo de Pesquisa, Ensino e Extensão em Pecuária (NUPEEC), Universidade Federal de Pelotas, CEP: 96010-610, Pelotas, Rio Grande do Sul, Brazil

E-mail: schmitt.edu@gmail.com

Received: Apr. 2, 2020

doi:10.5296/jas.v8i3.16793
Accepted: Apr. 27, $2020 \quad$ Published: Apr. 29, 2020

URL: https://doi.org/10.5296/jas.v8i3.16793

\begin{abstract}
This study aimed to assess the reproductive performance and body temperature of beef heifers supplemented with rumen-protected methionine (RPM) in an extensive grazing system and mated during the summer. One hundred 5/8 Angus 3/8 Brahman heifers were homogeneously divided into the control group $(n=48, C G)$ supplemented with mineral salt ad libitum and methionine group ( $\mathrm{n}=52, \mathrm{MG}$ ) who received the same supplementation plus $4 \mathrm{~g}$ of methionine per $100 \mathrm{~g}$ of mineral salt. The groups were fixed-time artificial inseminated (FTAI) 45 days after starting the supplementation. On day 0 of the FTAI protocol, ten animals per group received data-logger thermometers attached in progesterone implants recording the body temperature of the animals every 30 minutes. Pregnancy diagnosis was performed on days 30 and 60 after the artificial insemination to determine the rates of conception, pregnancy, and pregnancy loss. At the beginning of the supplementation, both groups had similar weights (MG was $304.6 \mathrm{~kg}$ and CG $304.4 \mathrm{~kg}$ ), while on days 0 and 30 about the FTAI protocol, the MG was higher weight (365.9 vs. 346.7 and 384.8 vs. $371.5 \mathrm{Kg}$ ). During the FTAI protocol, the MG had lower body temperatures ( 38.77 vs. $38.99^{\circ} \mathrm{C}$ ) and a tendency to
\end{abstract}


have larger dominant follicles than the CG $(11.76 \mathrm{~mm}$ x $10.8 \mathrm{~mm})$. Although it did not impact reproductive performance, the observed higher weight, dominant follicle sizes, and lower body temperatures during FTAI protocols show the potential benefits of methionine supplementation in beef heifers mated during the summer.

Keywords: amino acids, beef cattle, breeding, fixed timed artificial insemination, thermoregulation

\section{Introduction}

The major meat and milk producing regions of the world are found in tropical and subtropical climates characterized by large thermal amplitudes, which is a constant challenge for the thermoregulation of the animals to increase productivity. The damage caused by heat stress to the animals' reproductive and productive abilities has been widely discussed (Arias et al., 2008; Key et al., 2014; Wiltbank et al., 2017). Heat stress can have direct effects on tissues, and can indirectly cause systemic alterations due to a reduced feed intake, which then affects several metabolic processes that lead to decreases in production and performance (Baumgard et al., 2014).

Heat stress in cattle leads to changes in thermoregulatory mechanisms that promote body heat loss, combined with metabolic and hormonal responses that alter the use of substrates (Faylon et al., 2015). The circulating concentrations of non-esterified fatty acids (NEFA) are lower during heat stress, even with high levels of stress hormones, such as epinephrine, glucagon, and cortisol, which are potent lipolytic agents (Zhao et al., 2018). Pathways such as proteolysis are prioritized for energy production, an observation that continues to generate discussions on the mechanisms controlling nutrient partitioning during stress (Rhoads et al., 2009; Baumgard et al., 2013).

Although the ideal time for beef cattle breeding season in beef cattle happens when there is a more significant pasture offer (Pessoa et al., 2018), this generally corresponds to periods of higher temperatures and humidity. The increase of external temperature can to induce the increasing the body temperature, that in turn affect oocyte quality and follicle size (Castaño et al., 2014; Clements et al., 2017) as well to increase the pregnancy losses (Schüller et al., 2014; Schüller et al., 2017). Despite this, very few studies propose the use of additives in beef cows to attenuate the effects of environmental temperature on the reproductive performance of the herds.

On the other hand, in dairy cows nutritional strategies to attenuate the effects of heat stress have been constantly reviewed and improved (Ayasan and Karakozak, 2010; Conte et al., 2018). It recently has been showed that methionine and arginine supplementation could help maintain protein production in mammary gland cells exposed to high temperatures (Salama et al., 2019). As in mammary gland cells, methionine supplementation could also be beneficial for other cells during periods of high temperature and humidity. In mice, methionine restriction led to increases in body temperature and energy expenditure, which suggests that this amino acid has an important thermoregulatory function (Hasek et al., 2010). All studies in dairy cows, with findings on energetic gluconeogenic pathways supported by amino acids 
derived from proteolysis, methionine supplementation with a protective effect against heat stress in mammary gland cells, and action of methionine on thermoregulation, demonstrate great potential for further studies on methionine as a nutritional alternative against heat stress during periods of high temperature and humidity. Based on these studies, we hypothesize that supplementation with rumen-protected methionine during periods of high temperature can modulate body temperature and improve the reproductive performance of heifers subjected to a fixed-time artificial insemination (FTAI) protocol. In this context, our study aimed to assess the body temperature, follicle development, conception rates, and embryo loss rates in beef heifers supplemented with rumen-protected methionine and subjected to FTAI during periods of high temperature and humidity.

The overall objective was to investigate the response of heifers supplemented with RPM in terms of their body temperature, as well as to evaluate methionine's influence on pregnancy rates on day 30 after the FTAI. In addition, the possible effects of this supplementation on embryo loss rates were analyzed. The effect of supplementation on the average daily gain $(\mathrm{ADG})$ and the final weight $(\mathrm{FW})$ of the heifers were also investigated.

\section{Material and Methods}

All procedures were approved by the Animal Experimentation Ethics Committee of the Federal University of Pelotas (UFPEL), under code 5069. The experiment was carried out in a commercial beef cattle farm in the municipality of São Gabriel (30'13'54'S - 54³7'29' W). In September 2017, 100 Brangus (5/8 Angus 3/8 Brahman) heifers aged 17 to 19 months were selected, weighed, and categorized according to their body condition scores (BCS), where $1=$ very lean and $5=$ very fat (Lowman et al., 1973). On the same day, blood samples were collected for bovine herpesvirus (BoHV) seroneutralization and to verify persistent infections with Bovine Viral Diarrhea Virus (BVDV) by direct ELISA (Idexx BVDV Ag/Serum Plus, Idexx Laboratories, Westbrook, USA). Animals identified as positive for these diseases were not included in the experiment.

On October 31 (D-56), the weight and BCS of the animals were measured again. In addition, heifers were subjected to a gynecological ultrasound examination. Only heifers that were cycling and had no genital tract pathologies remained in the study. On this day, the animals were divided into two groups: Control Group, which received only mineral supplementation with a commercial formulation ( $\mathrm{CG} ; \mathrm{n}=48$ ), and Methionine Group, which received the same mineral supplementation but with the inclusion of methionine at a proportion of $4 \mathrm{~g}$ for each $100 \mathrm{~g}$ of mineral salt (MG; $\mathrm{n}=52$ ). The initial average weight of the groups was $304.4 \mathrm{~kg}$ and $304.6 \mathrm{~kg}$, respectively. Both groups were allocated to two similar pickets regarding area and forage availability $(\mathrm{CG}=63.5 \mathrm{ha}, \mathrm{MG}=68.3 \mathrm{ha})$.

Cows were grazed on native pastures. Both groups were grazed in the same native pasture variety and, therefore, any difference of the cow performance would be assigned to the treatment effect.

To analyze the forage resources, forage was collected using the double sampling method according to Wilm et al. (1944) to calculate the available forage mass. In an area of $0.25 \mathrm{~m} 2$, 
the forage was cut close to the soil and areas of root clumps were excluded. Forage samples were collected in paper bags, weighed to calculate forage availability, and stored. Subsequently, samples were dried in the laboratory in a forced air oven (Biopar, RS, Brazil, model S836SD) at $70{ }^{\circ} \mathrm{C}$ for $48 \mathrm{~h}$ to determine the amount of dry matter (DM), and then sent for bromatological analysis on nutrition lab at NUPEEC in Federal University of Pelotas. These analyses were realized at three different timepoints (D-45, D0, and D60, considering day 0 of the FTAI protocol the D0.) throughout the study. The farm is certified by the international organization Alianza del Pastizal ${ }^{\circledR}$ (BirdLife International, Cambridge, UK), which certifies that the cows are raised and maintained on native pasture. The native forage species with the highest prevalence in the area were Andropogon lateralis, Aristida laevis, Axonopus affinis, Paspalum plicatulum, and Paspalum notatum. The initial forage availability (842.6 and $728.3 \mathrm{~kg} \mathrm{DM} / \mathrm{ha}$ for the $\mathrm{CG}$ and $\mathrm{MG}$, respectively) was considered sufficient for the animals according to the dry matter intake estimates proposed by Barioni et al. (2008) as shown in Table 1.

Table 1. Values of dry matter (DM), crude ash (CA), ethereal extract (EE), crude protein (CP), neutral detergent fiber (NDF), and acid detergent fiber (FDA) at the three moments of pasture collection on the days -45 (D-45), 0 (D0), and 60 (D60) in relation to the FTAI protocol during all experimental period

\begin{tabular}{lcccccc}
\hline & \multicolumn{3}{c}{ Control Group (CG) } & \multicolumn{3}{c}{ Methionine Group (MG) } \\
\hline & D-45 & D0 & D60 & D-45 & D0 & D60 \\
\hline Dry matter kg/ha & 916 & 832 & 780 & 710 & 780 & 695 \\
Crude ash (\%) & 7,3 & 6,2 & 6,2 & 10,1 & 6,2 & 6,4 \\
Ethereal extract & 1,4 & 2,2 & 3,7 & 1,2 & 3,0 & 2,1 \\
Crude protein (\%) & 8,6 & 8,3 & 7,5 & 10,9 & 8,0 & 8,4 \\
NDF (\%) & 64,3 & 70,9 & 70,96 & 61,32 & 75,23 & 69,22 \\
ADF (\%) & 32,8 & 31,7 & 33,34 & 31,19 & 41,3 & 34,2 \\
\hline
\end{tabular}

$\mathrm{NDF}=$ Neutral detergent fiber; $\mathrm{ADF}=$ Acid detergent fiber

Both groups received the same mineral supplement of the control group during the 15-day adjustment period. The composition of the supplement is shown in Table 2.

Table 2. Minerals and ingredients of diets in the control group (CG) and methionine group (MG) during experimental period

\begin{tabular}{lcc}
\hline \multicolumn{1}{c}{ Ingredient } & Control Group (CG) & Methionine Group (MG) \\
\hline Native pasture & Ad libitum & Ad libitum \\
Calcium & $150 \mathrm{~g} / \mathrm{kg}$ & $150 \mathrm{~g} / \mathrm{kg}$ \\
Phosphorus & $55 \mathrm{~g} / \mathrm{kg}$ & $55 \mathrm{~g} / \mathrm{kg}$ \\
Sodium & $50 \mathrm{~g} / \mathrm{kg}$ & $50 \mathrm{~g} / \mathrm{kg}$ \\
Sulfur & $10.5 \mathrm{~g} / \mathrm{kg}$ & $10.5 \mathrm{~g} / \mathrm{kg}$ \\
Zinc & $2100 \mathrm{mg} / \mathrm{kg}$ & $2100 \mathrm{mg} / \mathrm{kg}$ \\
Manganese & $525 \mathrm{mg} / \mathrm{kg}$ & $525 \mathrm{mg} / \mathrm{kg}$
\end{tabular}




\section{MlMacrothink}

Copper

Iodine

Cobalt

Selenium

Lasalocid sodium

Methionine
Journal of Agricultural Studies

ISSN 2166-0379

2020, Vol. 8, No. 3

$420 \mathrm{mg} / \mathrm{kg}$

$31.5 \mathrm{mg} / \mathrm{kg}$

$15.8 \mathrm{mg} / \mathrm{kg}$

$10.5 \mathrm{mg} / \mathrm{kg}$

$1800 \mathrm{mg} / \mathrm{kg}$
$420 \mathrm{mg} / \mathrm{kg}$

$31.5 \mathrm{mg} / \mathrm{kg}$

$15.8 \mathrm{mg} / \mathrm{kg}$

$10.5 \mathrm{mg} / \mathrm{kg}$

$1800 \mathrm{mg} / \mathrm{kg}$

$40 \mathrm{~g} / \mathrm{kg}$

After this period, the MG received the rumen-protected methionine mixture (Smartamine ${ }^{\circledR} \mathrm{M}$, Adisseo, Antony, France) + mineral supplement. The supplement was provided ad libitum, and the intake was controlled weekly, in wooden troughs protected from rain. The supplement was provided for a period of 105 days until the end of the experiment.

After 30 days of supplementation, estrus synchronization was performed for fixed-time artificial insemination (FTAI). Before placing the progesterone intravaginal device (IVD), a new gynecological exam was performed in the heifers to assess the size of the follicles and/or the presence of corpus luteum. The synchronization protocol used is as follows: day 0 (D0),

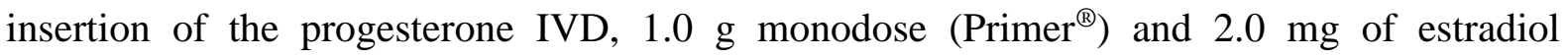
benzoate (EB) $\left(\mathrm{RIC}^{-B E^{\circledR}}{ }^{\circledR}\right.$ intramuscularly (IM); on D8, after removing the IVD, $0.15 \mathrm{mg}$ of D-Cloprostenol (Prolise ${ }^{\circledR}$ ) was administered IM. After 24 hours (D9), $1.00 \mathrm{mg}$ of EB was administered IM, and FTAI was performed 28 hours after (D10). In 20 animals (10 in each group), randomly selected, the body temperature between D0 and D8 (during the period with the IVD) was monitored at 30 minute intervals using a data logger (Ibutton ${ }^{\circledR}$, Thermochron, Whitewater, USA) coupled to the IVD according to the method proposed by Hansen (2012).

When the IVD was removed, the ovaries were analyzed to measure the size of the dominant follicle of a subset of the 20 animals whose temperatures were measured; this analysis was repeated on days 9 and 10 of the protocol. Transrectal ultrasonography (Mindray DP-2200, Shenzhen, China) with a $5 \mathrm{MHz}$ probe was the method used. On D9 and D10, the body temperature was also measured by rectal examination using a digital thermometer. On D10, in the afternoon, starting at 2:00 p.m., FTAI was performed. All semen used belonged to the same bull and to the same freezing lot, previously analyzed for its physical, morphological, and thermoresistance properties. The semen was thawed in water at $37^{\circ} \mathrm{C}$ for 30 seconds with the aid of an automatic defroster.

Seventeen days after artificial insemination, the estrus status was analyzed by visual detection in both groups for a 7-day period. Animals in estrus were inseminated after 12 hours the signals' observation. At the end of this period, two bulls were included in each group, which were rotationally changed every 15 days. Thirty days after the artificial insemination, a pregnancy diagnosis was performed by ultrasonography to determine the pregnancy after FTAI. The test was repeated 30 days later to determine pregnancy rates and pregnancy loss rates after another estrus cycle.

The animals were weighed when the groups were taken to the management center to perform a procedure, so measurements for both groups were performed at irregular intervals (D-56, D-18, D0, D42, and D76). An EziWeigh 7i electronic scale (Tru-Test®, Auckland, New 
Zealand) coupled with the containment unit was used to weigh the animals. After weighing, the BCS was assessed by visual observation, and were rated on a scale of 1-5 (1=very lean, $5=$ very fat) according to the scale described by Lowman et al. (1973).

The climate data were obtained with an interval of 1 hour using a mobile weather station (Instrutemp® ITWH-1080, São Paulo, Brazil) installed next to the farm management center. Based on this information, the temperature-humidity index (THI) was calculated. The formula used to calculate the THI was: $\mathrm{THI}=\mathrm{Ts}+0.36 \mathrm{Tdp}+41.2$ where $\mathrm{Ts}=$ dry bulb thermometer temperature and $\mathrm{Tdp}=$ dew point temperature. During the experiment, mean temperatures of $24.93{ }^{\circ} \mathrm{C}, 25.42{ }^{\circ} \mathrm{C}$, and $24.95{ }^{\circ} \mathrm{C}$ were observed for the months of December 2016, January 2017, and February 2017, respectively.

This study used a completely randomized design with two treatments (CG vs. MG). The experimental unit considered was each heifer. The statistical analyses for body weight and follicle diameter were performed using ProcMixed Models using the SAS Studio ${ }^{\circledR}$ software (SAS Institute Inc., Cary, USA). Analyses involving repeated measures over the time (e.g. weight $(\mathrm{kg})$, follicle diameter $(\mathrm{mm})$ were compared between treatments using ANOVA considering individual heifer as the RANDOM effect. Additionally, the model used for analysis of time-course data (repeated measures) included time (experimental day) as well as treatment $\times$ time interactions.

The conception and pregnancy rate analyses were performed by the Chi-square test using SAS Studio ${ }^{\circledR}$ software (SAS Institute Inc., Cary, USA). For the statistical analysis of body temperature, the same repeated measurements model was used, with group and experimental day as fixed variables and body temperature $\left({ }^{\circ} \mathrm{C}\right)$ as the response variable. The results are presented as means \pm standard error of the mean.

\section{Results}

During the experimental period, the animals of both treatments had been daily mineral supplement intake corresponding to $100 \mathrm{~g} / \mathrm{animal} /$ day of the mixture, which correspond that the MG had a consumption of $4 \mathrm{~g}$ of methionine/day, and it is the only difference in the mineral supplementation.

Forage availability for the MG and CG pickets was 710, 780, and 695; and 916, 832, and 780 $\mathrm{kg} \mathrm{DM} / \mathrm{ha}$, respectively, for samples collected on D-45, D0 and D60 of the experiment. The results of forage availability and bromatological analysis are shown in Table 1.

The ADG throughout the experimental period was $0.706 \mathrm{~kg} /$ day for the MG and $0.637 \mathrm{~kg} /$ day for CG, and the MG had higher weights on days D0 and D30 in relation to the FTAI protocol $(\mathrm{P}<0.03)$ (Figure 1). These differences influenced the $\mathrm{FW}$, which was higher for the $\mathrm{MG}$ $(398.57 \pm 28.47 \mathrm{~kg}$ vs. $389.27 \pm 21.44 \mathrm{~kg} ; \mathrm{P} \leq 0.01)$. 


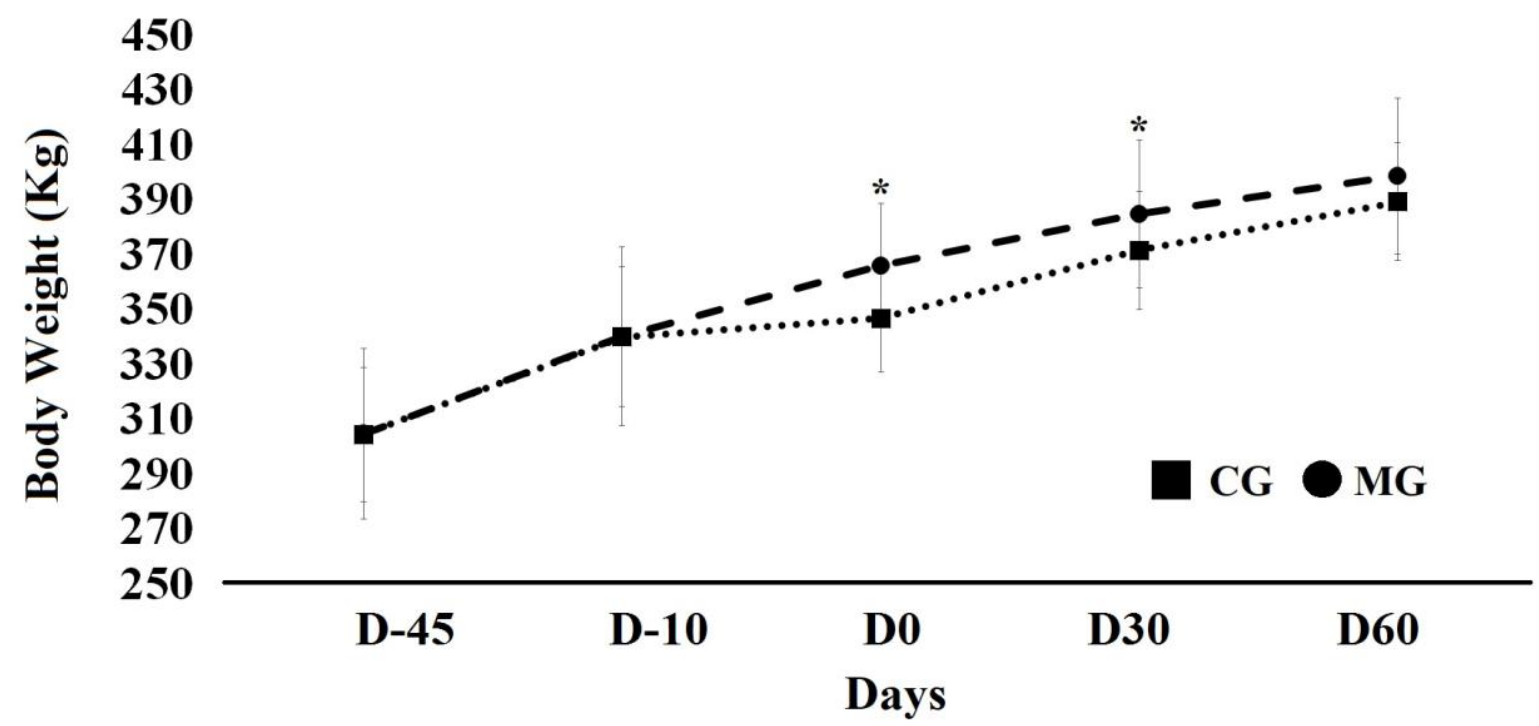

Figure 1. Evolution of body weight $(\mathrm{Kg})$ in heifers of the control group $(\mathrm{CG})$ and methionine group (MG) during all experimental period. $* \mathrm{P} \leq 0.05$ (Tukey)

The minimum, mean, and maximum values of THI in the experimental period are shown in Table 3.

Table 3. Temperature-humidity index (THI) minimum, medium and maximum during the first nine days in the fixed-time artificial insemination protocol (FTAI)

\begin{tabular}{llllllllll}
\hline THI & D0 & D1 & D2 & D3 & D4 & D5 & D6 & D7 & D8 \\
\hline Minimum & 62,34 & 62,05 & 63,54 & 63,34 & 65,44 & 64,34 & 65,14 & 62,04 & 62,34 \\
Medium & 63,35 & 64,93 & 65,91 & 67,96 & 68,01 & 70,75 & 70,54 & 68,35 & 65,12 \\
Maximum & 66,75 & 67,95 & 70,45 & 73,95 & 73,65 & 79,15 & 78,55 & 74,15 & 65,55 \\
\hline
\end{tabular}

Between D0 and D6, when the highest THI values were recorded, considering as heat stressed heifers when the THI is higher than 73, because it already shows effects on the reproduction (Schüller et al., 2014), the MG had lower mean body temperature values $(\mathrm{P} \leq 0.01)$, which was also observed at different timepoints during the implementation of the protocol $(\mathrm{P} \leq 0.01)$. However, on the days before the FTAI, there was a reduction in the THI and body temperatures. Those differences no longer existed during less challenging climate periods, THI lower than 73 (Figure 2). 


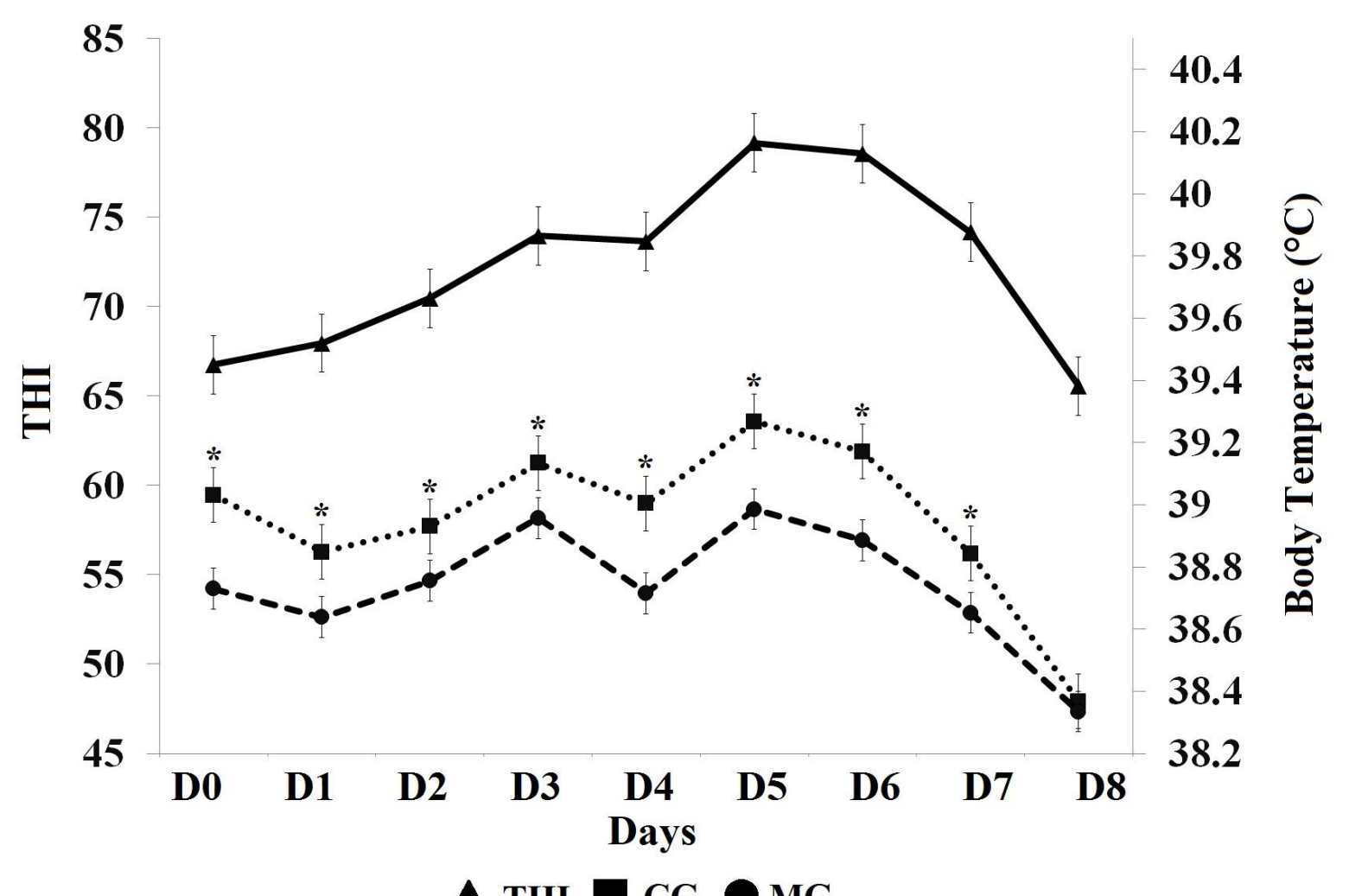

Figure 2. Relationship between body temperature $\left({ }^{\circ} \mathrm{C}\right)$ in heifers of the control group (CG) and methionine group (MG) and the temperature-humidity index (THI) during the first nine days in the fixed-time artificial insemination protocol (FTAI). ${ }^{*} \mathrm{P} \leq 0.05$ (Tukey)

MG heifers had a tendency to larger follicles $(11.76 \mathrm{~mm} \pm 2.07 \times 10.86 \mathrm{~mm} \pm 2.75, \mathrm{P}=0.06)$. This difference was mainly determined by differences on D8 and D9 $(\mathrm{P}<0.05)$; however, these differences disappeared on D10, suggesting that the control group may have had a higher growth rate during this period, although no statistical difference was observed for this variable, that is probably because of the size of the subset (Figure 3). 


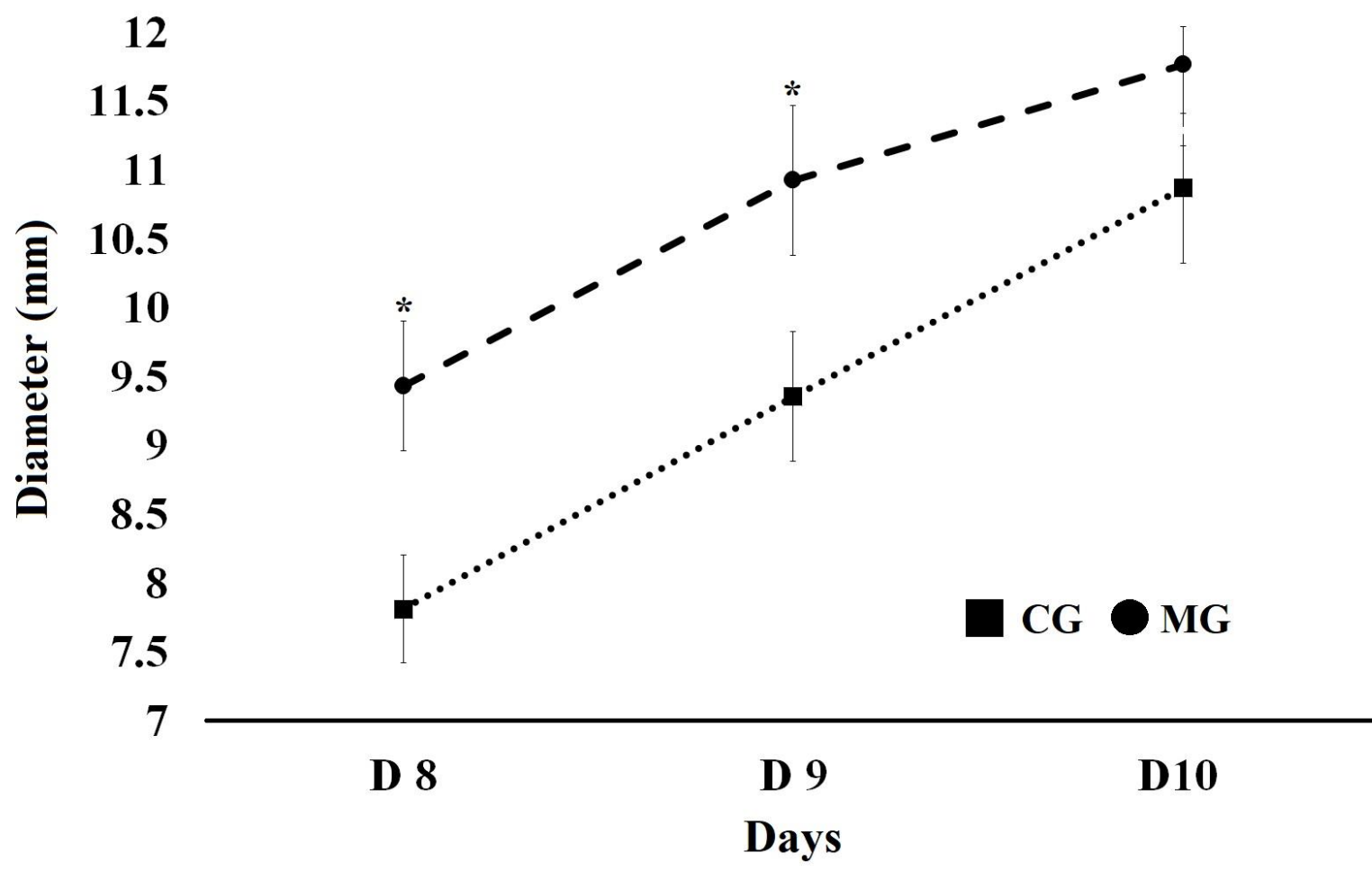

Figure 3. Follicle diameter ( $\mathrm{mm})$ in heifers of the control group (CG) and methionine group (MG) during the last three days in the fixed-time artificial insemination (FTAI). ${ }^{*} \mathrm{P} \leq 0.05$ (Tukey)

There were no differences in conception and pregnancy rates 30 and 60 days after the FTAI, with values of $42.3 \%(22 / 52)$ and $76.9 \%$ (40/52) for the MG and 39.5\% (19/48) and $79.1 \%$ (38/48) for the CG, as shown in Table 4.

Table 4. Pregnancy rates (\%) at day 30 (D30) and day 60 (D60) in relation to the FTAI protocol in heifers of the control group (CG) and methionine group (MG)

\begin{tabular}{lccc}
\hline Pregnancy rates (\%) & Control Group (CG) & Methionine Group (MG) & P Value \\
\hline D30 & $39,5(19 / 48)$ & $43,3(22 / 52)$ & P>0,05 \\
D60 & $79,1(38 / 48)$ & $76,9(40 / 52)$ & P $>0,05$ \\
\hline
\end{tabular}

There were no significant differences in BCS. The initial BCS of the heifers presented the following distribution in the CG: $6.25 \%$ score 2, 52.08\% score 2.5 and $41.67 \%$ score 3 and at the end of the experiment had $41.67 \%$ score 3.5 and $58.33 \%$ score 4 . In the GM they had the following distribution: $9.6 \%$ score $2,44.2 \%$ score $2.5,44.2 \%$ score 3 and $2 \%$ score 3.5 . At the end of the experiment $2 \%$ score $3,36.5 \%$ score $3.5,59.5 \%$ score 4 and $2 \%$ score 4.5 .

\section{Discussion}

Methionine supplementation has been shown to improve growth performance in cattle (Schroeder et al., 2006). This was further confirmed in our study as there was a greater weight gain in the MG group, especially in December and January, which registered higher environmental temperatures. Despite the differences in animal category and nutritional management, similar results were found in Nellore steers at 12 months of age in a grazing 
system with Brachiaria and supplementation with essential fatty acids plus methionine (FEFA and EFA), demonstrating that methionine supplementation should be considered for animals at the end-stage (Fernandes et al., 2008), and can be used to reduce the incidence of metabolic disorders in ruminants (Gomez et al., 2011). The ideal supplementation of methionine is responsible for more retention of nitrogen (Schroeder et al., 2006) and it has been proved to rumen-protected methionine and lysine may enhance gain efficiency and dietary energetics in growing animals (Torrentera et al., 2017).

In a forage-based diet, the fewer methionine levels can compromise the productivity of ruminants (Veira et al., 1991). We speculated that it could be related to the effects of the methionine restriction on biochemical and physiological responses that limit the accumulation of fat in tissues. It has been recently shown that this amino acid is directly related to the expression of the uncoupling protein-1 (UCP1) protein, which is responsible for the decoupling of cellular respiration in mitochondria, which in turn is directly related to increased energy expenditure, weight loss, and increased body temperature of the animals (Brondani et al., 2012). The restriction of this amino acid promotes the regulation of lipogenic genes in the liver, resulting in a lower hepatic capacity to synthesize and export lipids, in addition to altering the capacity of white adipose tissue to synthesize and oxidize fatty acids (Hasek et al., 2013).

During the ovulation synchronization period of heifers, the measured THI reached values higher than 75, as shown in Table 4, and negative reproductive effects were already observed for THI close to 73 (Schüller et al., 2014). Analysis of the impact of climate factors from 7 days before the FTAI to 3 days after the protocol in Hereford and Hereford x Angus cows by Biggers et al. (1987) showed that THI increases lead to lower conception rates (23\% with $\mathrm{THI} \geq 80$ ). Heat stress also causes a decrease in the intensity of the estrus signs, coloration of the mucosa of the vagina, and size of the dominant follicle, after one-point increases in the THI on the day of estrus (Schüller et al., 2017). However, this study with heifers showed that the two groups had similar pregnancy rates. However, this study with heifers showed that the two groups had similar pregnancy rates. The whole protocol period was marked with high THI and a significant difference in the internal temperature between treatments, only the last protocol day marked with decreasing of THI and no differences groups in internal temperature. This fact could have contributed to no group differences in the pregnancy rates already that the critical phase of heat stress in the ruminants fertility is when the embryo has two to four cells corresponding to the day 2 - 3 after ovulation (Edwards and Hansen, 1996).

The lower body temperatures in heifers of the MG could be explained by an insufficient amount of methionine in the control group, thus affecting metabolic flexibility and thermoregulation as discussed previously (Hasek et al., 2010). UCP1 is a protein in the inner mitochondrial membrane that assists in the transfer of protons $(\mathrm{H}+)$ to the interior of the mitochondria, but this movement only causes the release of heat and does not lead to ATP formation. It has recently been shown that methionine restriction increases the number and size of mitochondria in inguinal white adipose tissue cells, expression of UCP1, respiratory proteins, and citric acid cycle enzymes. This, in turn, increases the oxidative capacity of mitochondria (Patil et al., 2015). These mechanisms directly impact the generation of heat, 
which suggests that supplementation with this amino acid could increase adaptability in highly-challenging thermoregulation situations. The amino acid profile of the pastures and the effective absorption of each amino acid is still poorly understood, and our study shows the requirement of further knowledge in this area. As previously mentioned, proteolysis in dairy cows exposed to high temperatures is an important pathway for energy production (Baumgard et al., 2013), which apparently can also be applied to heifers exposed to high temperatures, as these animals had higher weight gains and lower body temperatures when supplemented with amino acids. However, the effects of methionine on the microbiota of the small intestine could also directly interfere with the absorption of nutrients, leading to higher weight gains (Shoveller et al., 2005).

MG heifers had larger follicles at the time of insemination, as already demonstrated in Bos taurus $\mathrm{x}$ Bos indicus heifers supplemented with methionine and urea, which had a higher percentage of follicles larger than $9 \mathrm{~mm}$ (Alonso et al., 2008). Increases in body temperature can impact follicle stimulating hormone concentrations, thus compromising follicle growth, estrogen synthesis, estrus manifestations, and luteinizing hormone peaks (Nardone et al., 2010; Li et al., 2016), which then affects follicle size at the time of ovulation. This information is concordant with the results found in the experiment with heifers. Although pregnancy rates in heifers with larger follicles at the time of ovulation $(\geq 12.8 \mathrm{~mm})$ are expected to be higher than those in heifers with smaller follicles $(\leq 10.7 \mathrm{~mm})$ (Perry et al. 2007), we were unable to observe this in our study. Marked effects on weight gain, body temperature throughout the FTAI protocol, and increases in follicle size and pregnancy rates in this study were not influenced by these factors, which suggests that other factors, such as mild temperatures after the FTAI, a well-conducted transfer, and a correct bull-to-cow ratio, ensured good pregnancy rates for both groups.

\section{Conclusion}

In conclusion, the results of this study show that methionine supplementation in Brangus heifers in a native pasture leads to increases in weight gain and size of the dominant follicle and decreased the internal temperature during the periods with high THI.

\section{References}

Alonso, L., Maquivar, M., Galina, C. S., Mendoza, G. D., Guzmán, A., Estrada, S., ... Molina, R. (2008). Effect of ruminally protected methionine on the productive and reproductive performance of grazing Bos indicus heifers raised in the humid tropics of Costa Rica. Trop. Anim. Health Prod., 40, 667-672. https://doi.org/10.1007/s11250-008-9146-1

Arias, R. A., Mader, T. L., \& Escobar, P. C. (2008). Factores climáticos que afectan el desempeño productivo del ganado bovino de carne y leche. Arch. Med. Vet., 40, 7-22. https://doi.org/10.4067/S0301-732X2008000100002

Ayașan, T., \& Karakozak, E. (2010). Nutrition of donor cows. Kafkas Üniversitesi Veteriner Fakültesi Dergisi, 16(3), 523-530. https://doi.org/10.9775/kvfd.2009.1365

Barioni, L. G., Ferreira, A. C., Guimarães Junior, R., Marta Junior, G. B., \& Ramos, A. K. B. (2008). Tabelas para estimativas de ingestão de material seca de bovinos de corte em crescimento em pastejo. Comunicado Técnico EMBRAPA, 142. 
Baumgard, L. H., \& Rhoads, R. P. (2013). Effects of heat stress on postabsorptive metabolism and energetics. Annual Review of Animal Biosciences, 1, 311-337. https://doi.org/10.1146/annurev-animal-031412-103644

Baumgard, L. H., Abuajamieh, M. K., Stoakes, S. K., Sanz-Fernandez, M. V., Johnson, J. S., \& Rhoads, R.P. (2014). Feeding and managing cows to minimize heat stress. Tri-State Dairy Nutrition Conference, 14-16.

Biggers, B. G., Geisert, R. D., Wetteman, R. P., \& Buchanan, D. S. (1987). Effect of heat stress on early embryonic development in the beef cow. Journal of Animal Science, 64(5), 1512-1518. https://doi.org/10.2527/jas1987.6451512x

Brondani, L. A., Assmann, T. S., Duarte, G. C., Gross, J. L., Canani, L. H., \& Crispim, D. (2012). The role of the uncoupling protein 1 (UCP1) on the development of obesity and type 2 diabetes mellitus. Arq. Bras. Endocrinol. Metab., 56, 215-225. https://doi.org/10.1590/S0004-27302012000400001

Castaño, F. A., Rugeles, C. C., Betancur, C. A., \& Ramirez, C. J. (2014). Impacto del estrés calórico sobre la actividad reproductiva en bovinos y consideraciones para mitigar sus efectos sobre la reproducción. Biosalud., 13, 84-94.

Clements, A. R., Ireland, F. A., Freitas, T., Tucker, H., \& Shike, D. W. (2017). Effects of supplementing methionine hydroxy analog on beef cow performance, milk production, reproduction, and preweaning calf performance. J. Anim. Sci., 95, 5597-5605. https://doi.org/10.2527/jas2017.1828

Conte, G., Ciampolini, R., Cassandro, M., Lasagna, E., Calamari, L., Bernabucci, U., \& Abeni, F. (2018). Feeding and nutrition management of heat-stressed dairy ruminants. Ital. $J$. Anim. Sci. 17, 604-620. https://doi.org/10.1080/1828051X.2017.1404944

Edwards, J. L., \& Hansen, P. J. (1996). Elevated temperature increases heat shock protein 70 synthesis in bovine two-cell embryos and compromises function of maturing oocytes. Biology of Reproduction, 55(2), 341-346. https://doi.org/10.1095/biolreprod55.2.341

Faylon, M. P., Baumgard, L. H., Rhoads, R. P., \& Spurlock, D. M. (2015). Effects of acute heat stress on lipid metabolism of bovine primary adipocytes. J. Dairy Sci., 98, 8732-8740. https://doi.org/10.3168/jds.2015-9692

Fernandes, L. B., Franzolin, R., Franco, A. V. M., \& Carvalho, G. (2008). Aditivos orgânicos no suplemento concentrado de bovinos de corte mantidos em pastagem. Rev. Bras. Saúde Prod. Anim., 9, 231-238.

Gomez, A., Mendoza, G. D., Garcìa-Bojalil, C., Barcena, R., Ramos, J. A., Crosby, M. M., ... Lara, A. (2011). Effect of supplementation with urea, blood meal, and rumen-protected methionine on growth performance of Holstein heifers grazing kikuyu pasture. Trop. Anim. Health Prod., 43, 721-724. https://doi.org/10.1007/s11250-010-9759-Z

Hansen, P. J. (2012). Solutions to infertility caused by heat stress. Retrieved on 25 June 2019 from https://articles.extension.org/pages/64288/solutions-to-infertility-caused-by-heat-stress

Hasek, B. E., Boudreau, A., Shin, J., Feng, D., Hulver, M., Van, N. T., ... Gettys, T. W. (2013). Remodeling the integration of lipid metabolism between liver and adipose tissue by dietary methionine restriction in rats. Diabetes, 62, 3362-3372. https://doi.org/10.2337/db13-0501

Hasek, B. E., Stewart, L. K., Henagan, T. M., Boudreau, A., Lenard, N. R., Black, C., ... 
Gettys, T. W. (2010). Dietary methionine restriction enhances metabolic flexibility and increases uncoupled respiration in both fed and fasted states. Am. J. Physiol. Regul. Integr. Comp. Physiol., 299, 728-739. https://doi.org/10.1152/ajpregu.00837.2009

Key, N., Sneeringer, S., \& Marquardt, D. (2014). Climate Change, Heat Stress, and U.S. Dairy Production, ERR-175, U.S. Department of Agriculture, Economic Research Service, https://doi.org/10.2139/ssrn.2506668

Li, L., Wu, J., Luo, M., Sun, Y., \& Wang, G. (2016). The effect of heat stress on gene expression, synthesis of steroids and apoptosis in bovine granulosa cells. Cell Stress Chaperones, 21, 467-475. https://doi.org/10.1007/s12192-016-0673-9

Lowman, B.G., Scott, N., \& Somerville, S. (1973). Condition scoring beef cattle. East of Scotland College of Agriculture, 8.

Nardone, A., Ronchi, B., Lacetera, N., Ranieri, M. S., \& Bernabucci, U. (2010). Effects of climate changes on animal production and sustainability of livestock systems. Livest. Sci., 130, 57-69. https://doi.org/10.1016/j.livsci.2010.02.011

Patil, Y. N., Dille, K. N., Burk, D. H., Cortez, C. C., \& Gettys, T. W. (2015). Cellular and molecular remodeling of inguinal adipose tissue mitochondria by dietary methionine restriction. J. Nutr. Biochem., 26, 1235-1247. https://doi.org/10.1016/j.jnutbio.2015.05.016

Perry, G. A., Smith, M. F., Roberts, A. J., MacNeil, M. D., \& Geary, T. W. (2007). Relationship between size of the ovulatory follicle and pregnancy success in beef heifers. $J$. Anim. Sci., 85, 684-689. https://doi.org/10.2527/jas.2006-519

Pessoa, G. A., Martini, A. P., Filho, M. F. S., \& Rubin, M. I. B. (2018). Resynchronization improves reproductive efficiency of suckled Bos taurus beef cows subjected to spring-summer or autumn-winter breeding season in South Brazil. Theriogenology, 122, 14-22. https://doi.org/10.1016/j.theriogenology.2018.08.021

Rhoads, M. L., Rhoads, R. P., VanBaale, M. J., Collier, R. J., Sanders, S. R., Weber, W. J., ... Baumgard, L. H. (2009). Effects of heat stress and plane of nutrition on lactating Holstein cows: I. Production, metabolism, and aspects of circulating somatotropin. J. Anim. Sci., 92, 1986-1997. https://doi.org/10.3168/jds.2008-1641

Salama, A. A. K, Duque, M., Wang, L., Shahzad, K., Olivera, M., \& Loor, J. J. (2019). Enhanced supply of methionine or arginine alters mechanistic target of rapamycin signaling proteins, messenger RNA, and microRNA abundance in heat-stressed bovine mammary epithelial cells in vitro. J. Dairy Sci., 102, 2469-2480. https://doi.org/10.3168/jds.2018-15219

Schroeder, G. F., Titgemeyer, E. C., Awawdeh, M. S., Smith, J. S., \& Gnad, D. P. (2006). Effects of energy source on methionine utilization by growing steers. J. Anim. Sci., 84, 1505-1511. https://doi.org/10.2527/2006.8461505x

Schüller, L. K., Burfeind, O., \& Heuwieser, W. (2014). Impact of heat stress on conception rate of dairy cows in the moderate climate considering different temperature-humidity index thresholds, periods relative to breeding, and heat load indices. Theriogenology, 81, 1050-1057. https://doi.org/10.1016/j.theriogenology.2014.01.029

Schüller, L. K., Michaelis, I., \& Heuwieser, W. (2017). Impact of heat stress on estrus expression and follicle size in estrus under field conditions in dairy cows. Theriogenology, 102, 48-53. https://doi.org/10.1016/j.theriogenology.2017.07.004 


\section{Macrothink}

Shoveller, A. K., Stoll, B., Ball, R. O., \& Burrin, D. G. (2005). Nutritional and functional importance of intestinal sulfur amino acid metabolism. J. Nutr., 135, 1609-1612. https://doi.org/10.1093/jn/135.7.1609

Torrentera, N., Carrasco, R., Salinas-Chavira, J., Plascencia, A., \& Zinn, R. A. (2017). Influence of methionine supplementation of growing diets enriched with lysine on feedlot performance and characteristics of digestion in Holstein steer calves. Asian-Australasian journal of Animal Sciences, 30(1), 42. https://doi.org/10.5713/ajas.16.0181

Veira, D. M., Seoane, J. R., \& Proulx, J. G. (1991). Utilization of grass silage by growing cattle: effect of a supplement containing ruminally protected amino acids. Journal of Animal Science, 69(12), 4703-4709. https://doi.org/10.2527/1991.69124703x

Wilm, H. G., Costello, D. F., \& Klipple, G. E. (1944). Estimating forage yield by the double-sampling method. J. Am. Soc. Agron., 36, 194-203. https://doi.org/10.2134/agronj1944.00021962003600030003x

Wiltbank, M. C., Baez, G. M., Garcia-Guerra, A., Toledo, M. Z., Monteiro, P. L. J., Melo, L. F., ... Sartori, R. (2017). Momento y causa de perdidas fisiológica de la prenhez (no relacionada con enfermedad) en vacas lecheras lactantes y receptoras de embriones. Proceedings of the $12^{\circ}$ Simposio Internacional de Reproducción Animal, 30 August 2017, Córdoba, Argentina, 73-102.

Zhao, L., McMillan, R. P., Xie, G., Giridhar, S. G. L. W., Baumgard, L. H., El-Kadi, S., ... Rhoads, R. P. (2018). Heat stress decreases metabolic flexibility in skeletal muscle of growing pigs. Am. J. Physiol. Regul. Integr. Comp. Physiol., 315, 1096-1106. https://doi.org/10.1152/ajpregu.00404.2017

\section{Copyright Disclaimer}

Copyright for this article is retained by the author(s), with first publication rights granted to the journal.

This is an open-access article distributed under the terms and conditions of the Creative Commons Attribution license (http://creativecommons.org/licenses/by/4.0/). 